\title{
The Effect of Suitcase Concealment on Insect Colonization: A Pilot Study in Western Australia
}

\author{
Paola A Magni*, Christopher Petersen, Jonathon Georgy and Ian R Dadour \\ Medical, Molecular \& Forensic Sciences, Murdoch University, Australia
}

*Corresponding author: Paola A Magni, Medical, Molecular \& Forensic Sciences, Murdoch University, 90 South Street, Murdoch, Western Australia.

Received Date: March 11, 2019

Published Date: April 09, 2019

\begin{abstract}
Decomposition is a complex and continuous process that involves the breakdown of soft tissues following a death event. This is often mediated by the action of micro- and macro-fauna, especially necrophagous insects belonging to the Orders Diptera and Coleoptera. Access to the cadaver is a major prerequisite for decomposition to proceed. However, a cadaver maybe concealed to avoid an easy discovery by the authorities. The present field study investigated the decomposition process of a carcass placed in a suitcase in Western Australia. A total of six pig carcasses (Sus scrofa L.) were used as a substitute for human cadavers. Five pigs were singularly placed in identical zip suitcases made of fabric and a sixth pig being fully exposed (control pig). As expected, the study showed that the rate of decomposition differed between the control pig and concealed pigs. The rate of decomposition of the control pig followed the typical pattern, in terms of stages of decomposition, and revealed the insect species involved in the process. Pigs inside the suitcases exhibited the characteristics of wet decomposition. This occurred despite no significant differences between the ambient temperature and the temperature inside the suitcases. However, the relative humidity inside of the suitcases was found to be statistically different and the pattern of insect succession varied between the concealed carcasses and the control pig. Carcass attendance by blow flies at the control occurred within minutes of positioning, and oviposition occurred within the first day. In contrast, blow flies were not observed visiting the suitcases until the next day, with oviposition on the external part of the suitcases not recorded until day 9 and inside the suitcases after day 14. The insect species also varied between those found inside the suitcases and on the control, with families Phoridae (scuttle flies) and Fanniidae (lesser house flies) being the most prevalent species inside the suitcases. This pilot study represents the first attempt in Australia to research decomposition of remains inside a suitcase.
\end{abstract}

Keywords: suitcase concealment; decomposition; Forensic entomology; Insect succession; Min PMI

\section{Introduction}

Forensic entomology is the study of insects and other arthropods that are part of a criminal case [1]. Knowledge of the insects found at a crime scene has assisted in many types of forensic investigations by providing information under certain conditions on where, when, and how a person died [1-3]. Since blowflies (Diptera: Calliphoridae) are usually the first necrophagous fauna to find a cadaver, they are the most important insect evidence collected at crime scenes. Different temperature and environmental conditions influence different species of blowflies and their arrival time on the cadaver [4]. The decomposition and the associated developmental stages of insect larvae located on remains are used by forensic entomologists to estimate the minimum time since death (minimum Post-Mortem Interval, minPMI) [5,6]. Forensic researchers have documented the known pattern of arthropod succession on cadavers in numerous localities and used this information to estimate the minPMI in cases where the time of death is unknown $[2,7]$. When estimating the minPMI, both intrinsic and extrinsic factors - factors related to the dead body and factors related to the environment where the body lays - may affect the rates and patterns of insect utilization of the remains [7]. Factors such as temperature, humidity and rainfall, as well as whether the cadaver is exposed or concealed may influence the rate of insect invasion [2,7]. In order to determine the decomposition process mediated by insect fauna, access to the carcass is a prerequisite. However, the cadaver may be concealed, on numerous occasions to avoid an easy discovery by the authorities. Examples include in vehicles [8,9], in houses $[10,11]$, underwater [12] and if a cadaver is buried or wrapped [1315]. While there have been a number of studies on concealment, 
the factors affecting blowfly accessibility to remains in suitcases have received little attention. A single study performed in the UK indicated that there was a delay of 1-3 days before oviposition was observed. This study was performed using two different types of suitcase placed outside at two different times, one month apart from each other and baited with a pig's head. Furthermore, this study did not consider how the remains decomposed inside the suitcases but focused on how larvae accessed the remains through the zipper. As well, no information was recorded on the type of zip used to seal either suitcase [16]. The remainder of information pertaining to remains in suitcases are all forensic cases, e.g in Brisbane (QLD, Australia) in 2000 a man was caught by the police carrying a suitcase with the torso, the arms and the leg of a man he murdered [17]; in 2015 a corpse was found in suitcase after being left for one month in a busy Tokyo train station [18]; and the remains of a child were found in a suitcase left alongside a South Australian highway [19]; and in March 2019, a woman was found inside a suitcase in a parked car Sydney (NSW, Australia) [20]. To date, no research regarding concealment of cadavers in suitcases has been conducted in Australia. However, during July 2016 there was a case in Perth, Western Australia, that was the impetus for this study, in which a dead female was hidden in a suitcase and later dumped in a river [21]. In order to address this dearth of information concerning decomposition in a suitcase, this study is the first attempt to compare the decomposition process, and the entomological data between an exposed pig and those concealed in a suitcase for a period of 42 days during the Austral autumn.

\section{Materials and Methods}

The experiment was conducted at the Murdoch University Veterinary Farm, Murdoch, Western Australia, Australia (S $32^{\circ} 4^{\prime} 17^{\prime \prime}$ E $\left.115^{\circ} 50^{\prime} 0.60^{\prime \prime}\right)$. It was documented over a period of six weeks between April and May 2017, Austral autumn. The field site was eucalypt woodland on a sandy soil, with the most frequent surrounding vegetation being grass trees (Xanthorrhoea preissii Endl.) and zamia palms (Macrozamia riedlei (Dell \& Bennett)). For this study, a total of 6 pig carcasses weighting $8.8 \pm 1.2 \mathrm{~kg}$ were used as a substitute for human cadavers. Pig carcasses were chosen as they are considered to best mimic of human decomposition $[22,23]$. The pigs were euthanized in accordance with animal ethics. The carcasses were received fresh and after being weighed, they were transported to the site. One pig carcass was used as a control and exposed for the whole duration of the experiment, while the remaining 5 pigs were placed into separate suitcases. Each pig was labeled with a unique number, referring to the suitcase number and the specific opening day (see details in section 2.2), while the control pig was simply referred as "Control" pig. The positioning of each pig was carefully designed so that they were all placed in the shade and apart from each other between a minimum of $25 \mathrm{~m}$ to a maximum of $28 \mathrm{~m}$.

\section{Control pig (Exposed)}

The Control pig was placed on the surface of the ground and left outside in the open air to decompose and attract insects naturally.
This pig was placed in a caged structure located at the site to protect it from scavenging. The fencing mesh was large enough for insect access, but excluded mammalian, avian and reptilian predators and scavengers. Photographs and notes were taken every day of the decomposing carcass until it reached advanced decay stage (first three weeks). Entomological changes to the Control pig were also documented at each sampling period via the use of photographs, notes, and sampling of the insect material present. Fly eggs, larvae and pupae as well as beetles were sampled daily for the first 19 days, then from day 21 to the end of the study, the sampling was conducted every 2-3 days (on day $23,25,28,30,33,36,38,42$ ) in order to match the sampling of the Control pig with the opening of the suitcases. Insect samples were collected randomly, both in/on the carcass and the surrounding area (below the carcass and around the carcass). All the samples were placed in ventilated screw cap containers, labeled with day of sampling and location of sampling and they were placed in a refrigerated container until processed in the laboratory. In the laboratory, three subsamples were made from each container. Insects of the first subsample were the beetles and any other arthropod excluding Diptera. These samples were placed in a killing jar and sacrificed using ethyl acetate and identified [24]. A second subsample was composed of half of the immature fly specimens collected and represented an array of different instars including eggs and larvae. These samples were morphologically identified following a hot water kill and then preserved in $70 \%$ ethanol [25]. The third subsample was composed of the other half of the immature fly specimens collected, but in this case the eggs and larvae were reared to the adult stage and identified [2]. Fly eggs and larvae were reared on a small tray of minced beef which was placed on sand in containers covered with mesh. The food source was removed when all the larvae were post-feeding. Fly pupae were then placed on sand in a ventilated screw cap container. After eclosion, the adult flies were sacrificed using ethyl acetate and morphologically identified [24,26-28].

\section{Experimental pigs (Suitcases pigs)}

The 5 pigs designated for decomposition in a concealed environment were each placed inside identical commercial suitcases (commonly described as 'travelling suitcases'). The suitcases were soft cases $72 \mathrm{~cm} \mathrm{(H)} \mathrm{x} 47 \mathrm{~cm}(\mathrm{~W}) \times 24 \mathrm{~cm}(\mathrm{D})$, made from black polyester fabric, with coil zipper measuring $10 \mathrm{~mm}$ across the closed teeth and $41 \mathrm{~mm}$ across the tape. Suitcase 1 was opened after 14 days (pig S1-14), suitcase 2 after 21 days (pig S221), suitcase 3 after 28 days (pig S3-28), suitcase 4 after 36 days (pig S4-36) and suitcase 5 after 42 days (pig S5-42). On each sampling day, prior to the opening of a suitcase, an external examination of all suitcases was completed to check for any changes to the outside of each suitcase. Records were made of the adult flies visiting, presence of egg clusters on the external part of the suitcases or zip, larvae and/or other insect activity, and/or any leaking fluids. On each specific day, when a suitcase was opened, photographs were taken and any insect material was collected. If there was significant insect colonization, a similar subsampling procedure as described for the Control pig was conducted. Observations and sampling of 
the external part of the suitcases were made each day following the setup of the experiment for the Control pig, while the insect collection inside of the suitcases was conducted only on the days designated for the suitcase opening (day 14, 21, 28, 36, 42).

\section{Environmental data}

Temperature data loggers (Easy $\log 囚)$ were used to record the temperature $\left({ }^{\circ} \mathrm{C}\right)$ and relative humidity $(\mathrm{RH})$ within the suitcases, as well as the ambient temperature and humidity of the study site. All data loggers were programmed to record temperature and humidity every 30 minutes throughout the study period. Rainfall data was obtained from the Murdoch University Weather Station. Temperature data were analyzed by one-way ANOVA and Paired sample t-tests, with level of significance set at $\mathrm{P}<0.05$. Calculations were performed using StatPlus:mac LE software package 2018.

\section{Results}

\section{Temperature, $\mathrm{RH}$ and rainfall}

Figure 1: Plot of the rainfall occurring at the study site and daily mean temperatures registered at the study site and inside each of the 5 experimental suitcases.

The plot of daily mean temperatures including the ambient temperature of study site and the inside of each suitcase over the 42-day period of the study is illustrated in (Figure1). The mean ambient temperature ranged from a minimum of $13.89{ }^{\circ} \mathrm{C}$ (day 41 of the experiment) to a maximum of $21.22^{\circ} \mathrm{C}$ (day 13). Inside suitcase 1 , over 14 days until opened, the mean temperature ranged from a minimum of $17.88^{\circ} \mathrm{C}$ (day 2) to a maximum of $21.90{ }^{\circ} \mathrm{C}$ (day 13); inside suitcase 2, over 21 days until opened, between 16.70
${ }^{\circ} \mathrm{C}$ (day 19) and $21.60{ }^{\circ} \mathrm{C}$ (day 13); inside suitcase 3 , over 28 days until opened, between $16.70{ }^{\circ} \mathrm{C}$ (day 19) and $21.75{ }^{\circ} \mathrm{C}$ (day 13); inside suitcase 4 , over 36 days until opened, between $15.00{ }^{\circ} \mathrm{C}$ (day 33) and $21.10^{\circ} \mathrm{C}$ (day 13); and inside suitcase 5 , over 42 days until opened, between $15.20^{\circ} \mathrm{C}$ (day 33) and $21.59^{\circ} \mathrm{C}$ (day 13).

Paired sample t-tests determined that there were no significant differences between the temperatures inside the suitcases and the ambient temperature (Table 1).

Table 1: Average temperatures $\left({ }^{\circ} \mathrm{C} \pm\right.$ S.D.) registered at the study site and inside each of the 5 experimental suitcases analysed via paired sample t-test.

\begin{tabular}{|c|c|c|c|c|c|c|}
\hline \multirow{4}{*}{$\begin{array}{c}\text { Average } \\
\text { temperature } \\
{ }^{\circ} \mathrm{C} \pm \text { S.D. }\end{array}$} & & \multicolumn{5}{|c|}{ Opening of } \\
\hline & & Suitcase 1 (14 days) & Suitcase 2 ( 21 days) & Suitcase 3 (28 days) & Suitcase 4 (36 days) & Suitcase 5 ( 42 days) \\
\hline & Ambient & $19.16 \pm 1.30$ & $18.46 \pm 1.47$ & $18.43 \pm 1.38$ & $17.90 \pm 1.74$ & $17.53 \pm 1.90$ \\
\hline & Suitcase & $19.42 \pm 1.30$ & $18.45 \pm 1.70$ & $18.49 \pm 1.39$ & $17.80 \pm 1.42$ & $17.63 \pm 1.73$ \\
\hline \multirow[b]{2}{*}{ Paired sample t-test } & p-value & 0.60 & 0.99 & 0.88 & 0.78 & 0.79 \\
\hline & $\begin{array}{c}\text { Critical } \\
\text { Value (5\%) }\end{array}$ & 2.06 & 2.02 & 2.00 & 1.99 & 1.99 \\
\hline
\end{tabular}


One-way analyses of variance performed on the temperatures recorded inside each of the suitcases during the period also determined that there were no significant differences. As one suitcase was removed from the experiment every 7 days the comparisons were determined based on the overlapping periods, all suitcases 1,2,3,4,5 $\mathrm{F}_{4,65}=0.46$, $\mathrm{p}=0.77$; for suitcases $2,3,4,5 \mathrm{~F}_{3,80}=0.37$, $\mathrm{p}=0.77$; for suitcases $3,4,5 \mathrm{~F}_{2,81}=0.36, \mathrm{p}=0.70$; for suitcases 4,5 $\mathrm{F}_{1,70}=0.39, \mathrm{p}=0.54$. The plot of daily mean relative humidity $(\mathrm{RH})$ of both the study site and the inside of each suitcase over the 42-day period of the study is illustrated in (Figure 2). The mean ambient $\mathrm{RH}$ ranged from a minimum of $49.93 \%$ (day 1 of the experiment) to a maximum of $92.59 \%$ (day 42 ). Inside suitcase 1 , over 14 days until opened, the mean RH ranged from a minimum of $70.60 \%$ (day 1 ) to a maximum of $86.20 \%$ (day 15 ); inside suitcase 2 , over 21 days until opened, between $71.00 \%$ (day 1) and $87.00 \%$ (day 7,8 ); inside suitcase 3, over 28 days until opened, between $70.80 \%$ (day 1) and $98.00 \%$ (day 28); inside suitcase 4, over 36 days until opened, ranged between $71.20 \%$ (day 1 ) and $99.30 \%$ (day 36 ); and inside suitcase 5 , over 42 days until opened, between $71.60 \%$ (day 1) and $100 \%$ (day 38-42). Paired sample t-tests determined that the average $\mathrm{RH}$ registered in the study site and inside of each of the suitcases was significantly different for the whole duration of the study (Table 2).

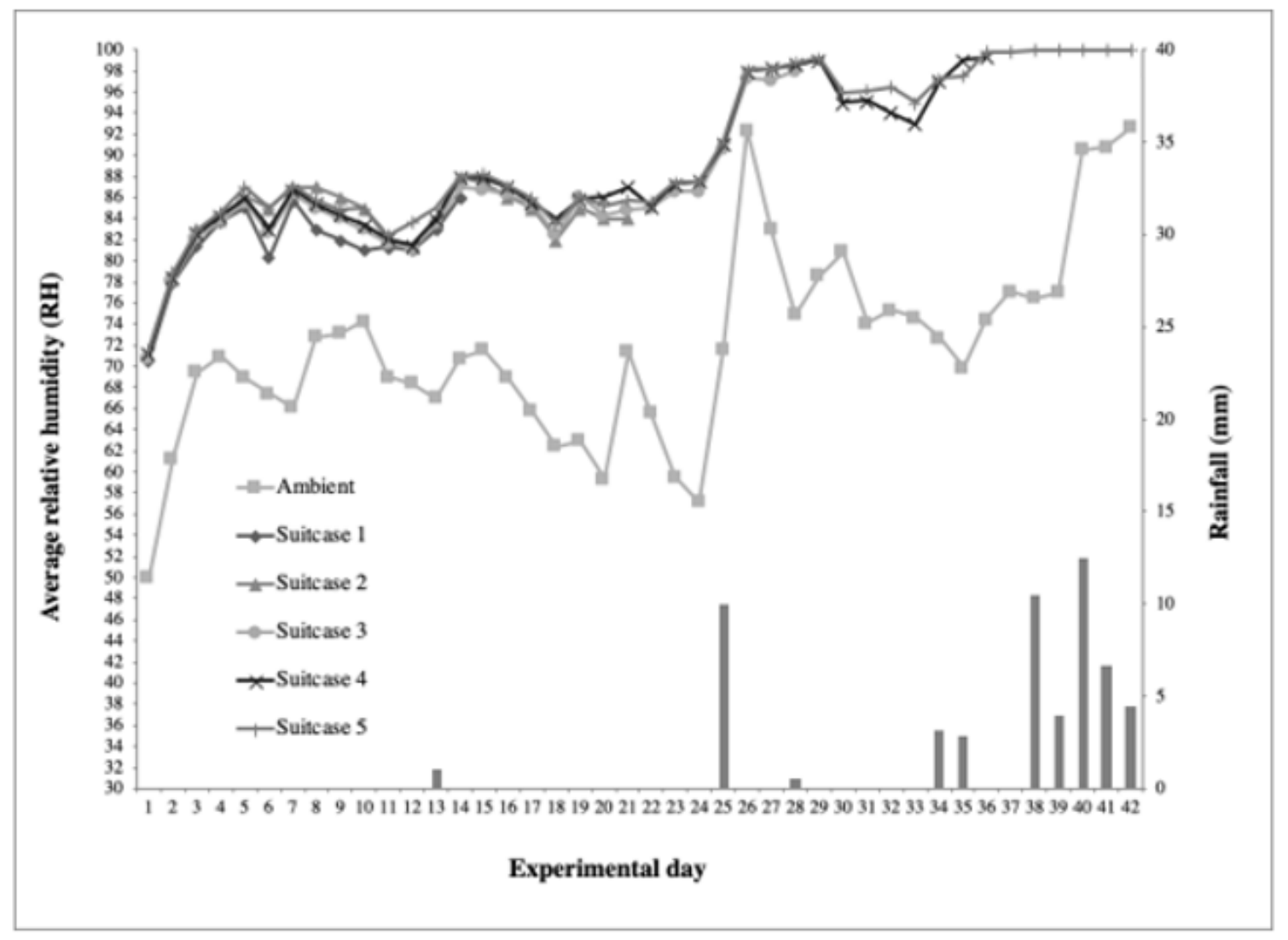

Figure 2: Plot of the rainfall and daily mean relative humidity occurring at the study site and inside each of the 5 experimental suitcases.

Table 2: Average relative humidity (RH\% \pm S.D.) registered at the study site and inside each of the 5 experimental suitcases analysed via paired sample t-test.

\begin{tabular}{|c|c|c|c|c|c|c|}
\hline \multirow{4}{*}{$\begin{array}{c}\text { Average relative } \\
\text { humidity RH\% } \pm \text { S.D. }\end{array}$} & & \multicolumn{5}{|c|}{ Opening of } \\
\hline & & $\begin{array}{c}\text { Suitcase } 1 \text { (14 } \\
\text { days) }\end{array}$ & $\begin{array}{c}\text { Suitcase } 2 \text { (21 } \\
\text { days) }\end{array}$ & $\begin{array}{c}\text { Suitcase } 3 \text { (28 } \\
\text { days) }\end{array}$ & $\begin{array}{c}\text { Suitcase } 4 \text { (36 } \\
\text { days) }\end{array}$ & $\begin{array}{c}\text { Suitcase } 5 \text { (42 } \\
\text { days) }\end{array}$ \\
\hline & Ambient & $68.06 \pm 5.97$ & $67.22 \pm 5.63$ & $68.42 \pm 7.97$ & $69.90 \pm 7.69$ & $71.92 \pm 9.13$ \\
\hline & Suitcase & $81.89 \pm 3.90$ & $83.84 \pm 3.74$ & $85.42 \pm 5.49$ & $88.38 \pm 6.67$ & $90.43 \pm 7.27$ \\
\hline \multirow{2}{*}{ Paired sample t-test } & $\mathrm{p}$-value & 0 & 0 & 0 & 0 & 0 \\
\hline & Critical Value (5\%) & 1.70 & 1.68 & 1.67 & 1.67 & 1.66 \\
\hline
\end{tabular}

One-way analyses of variance performed on the RH recorded inside each of the suitcases during the period of overlap determined that there were no significant differences (suitcases 1,2,3,4,5
$\mathrm{F}_{4,70}=0.60, \mathrm{p}=0.66$; suitcases $2,3,4,5 \mathrm{~F}_{3,80}=0.33, \mathrm{p}=0.80$; suitcases $3,4,5 \mathrm{~F}_{2,81}=0.26, \mathrm{p}=0.77$; suitcases $4,5 \mathrm{~F}_{1,70}=0.09, \mathrm{p}=0.77$ ). 
Rainfall is also illustrated in both Fig. 1 and 2. Rain occurred mainly towards the end of the study, including days $13(1 \mathrm{~mm}), 25$ (10mm), $28(0.5 \mathrm{~mm}), 34(3.2 \mathrm{~mm}), 35(2.8 \mathrm{~mm}), 38(10.5 \mathrm{~mm}), 39$ $(4 \mathrm{~mm}), 40(12.5 \mathrm{~mm}), 41(6.7 \mathrm{~mm})$ and $42(4.5 \mathrm{~mm})$.

\section{Decomposition}

Stages of decomposition were determined using those described by Payne [29]. Four observable stages were recognised for the Control pig: fresh, bloat, active decay and advanced decay (Figure 3, A-E). The fresh stage lasted approximately 2 days, followed by the bloat stage which lasted 9 days. The subsequent active decay stage continued for a further 10 days. The beginning and end points of the decomposition stages are mostly subjective and typically overlap, therefore it was proposed that the end of the bloat stage was delineated by the breaking of the skin and release of abdomen gases [29]. The body deflates at this point, resulting in the beginning of the decay stage. Advanced decay persisted from day 21 to day 42, when the carcass was completely skeletonized. As expected, the Control pig followed the typical pattern of decomposition [29], whereas the decomposition of the pigs in the suitcases did not follow any particular pattern previously described in the literature (Figure 3, F-L). Overall, the decomposition pattern of the pigs in the suitcases may be described as "wet decomposition". At the opening of the first suitcase, 14 days after the beginning of the experiment, common signs of decay typical of the fresh and the bloated stages (e.g. marbled appearance of the skin) were missing (Figure 3, F). The carcass appeared wet and strong odours were very noticeable. The fabric of the suitcases did not allow the fluids from the decomposing pig to drain and therefore the overall appearance of the carcass was "wet". During the first 14 days of the experiment only one short episode of rainfall was recorded (day $13,1 \mathrm{~mm}$ ). Overall, the stage of decomposition of the S1-14 pig was similar to the Control pig (Figure 3, A,F), with the only difference being the Control pig skin already broken, indicating the beginning of the active decay stage of decomposition, while the S1-14 pig skin was not broken yet, indicating that the carcass was still in bloat stage of decomposition. On day 21, both the Control pig and the S221 pig were in active decay (Figure 3, B, G). The major difference between the two carcasses was the presence of moisture associated with the pig in the suitcase compared to the Control pig. A small puddle was present at the base of the suitcase where the pig was located, which was not due to rainfall but the body fluids of the pig in the case of the Control pig, the body fluids were able to drain from the body and seep into the surrounding soil, avoiding the formation of the puddle. On day 28, the stages of decomposition of S3-28 pig versus the Control pig appeared very different (Figure 3, C, H). The Control pig was very dry with little soft tissue remaining indicating advanced decay, whereas the S3-28 pig was covered by fly larvae and it was laying in $10 \mathrm{~mm}$ of liquid, mostly due the retention of body fluids and the heavily rain recorded on day 25 of the study. There was not much change of the Control pig from day 36 right through today 42 , with the carcass in advanced decay/skeletonized (Figure 3, D, E). The remains of the Control pig on day 42 were only skin, hair and bones. Such remains are considered as "dry remains", even if they appear wet to touch, which was a consequence of the large amount of rain received towards the end of the study. At 36 days, the S4-36 pig had developed a toughened outer layer of soft tissue that had a brownish coloration, with the underlying tissue pink in color (Figure 3, I). At day 42, adipocere was evident under the toughened outer layer of brownish skin of the S5-42 pig (Figure 3, L).

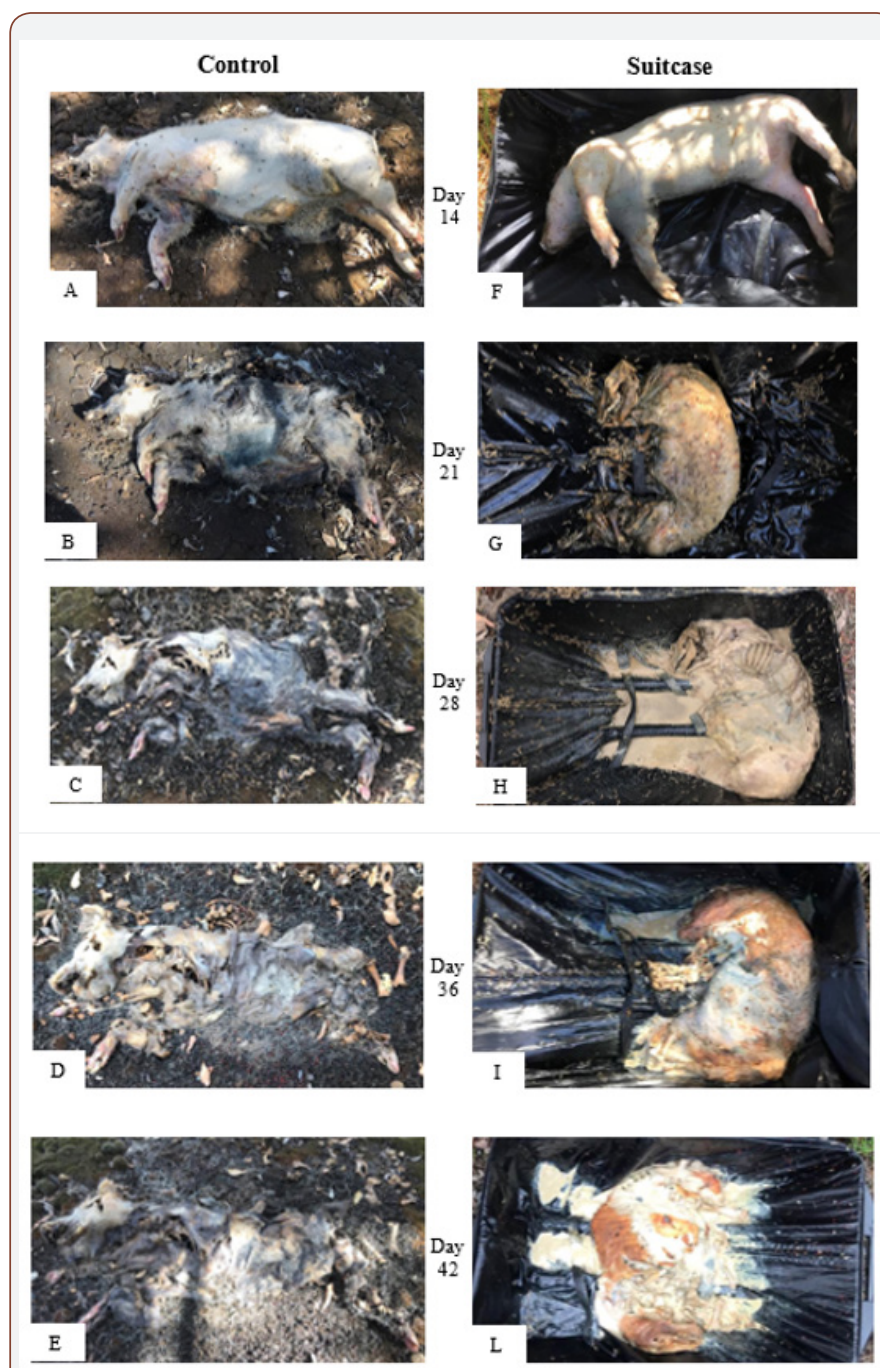

Figure 3: Comparison between the decomposition process of the control pig placed in the study site $(A, B, C, D, E)$ and the appearance of the pigs placed in the suitcases $(F, G, H, I, L)$ on the day of the suitcase opening: day $14(A, F)$, day $21(B, G)$, day 28 $(C, H)$, day $36(D, I)$ and day $42(E, L)$.

\section{Entomology}

Throughout the duration of the study, a total of nine insect taxa were identified to either genus or species during the decomposition of the Control pig (Table 3), representing three orders and six families. The same 9 insect taxa were also identified on the pigs in the suitcases (Table 4), however, none of the five suitcases contained all nine taxa. Suitcase 1 contained six species, suitcase 2 three species, suitcase 3 five species, suitcase 4 six species and suitcase 5 five species. As expected, representatives of the order Diptera were the first colonizers of the Control pig (from day 1), 
closely followed by representatives of the order Coleoptera as decomposition progressed (from day 9). In comparison, both Diptera and Coleoptera were present together on the external part of the suitcases since day 9 of the experiment (Table 5). With regards to Diptera, a total of 6 species were collected on the Control pig, 4 blowflies belonging to the family Calliphoridae (Chrysomya rufifacies (Macquart), Calliphora dubia (Macquart), C. albifrontalis Malloch and Lucilia sericata (Meigen)), one belonging to the family Muscidae, the greater housefly Muscina stabulans (Fallén) and one belonging to the family Fanniidae, the lesser housefly Fannia canicularis (L.). At the opening of the suitcases, only 2 calliphorids were identified (Ch. rufifacies and $C$. albifrontalis) beside $M$. stabulans and a representative of the family Phoridae, the scuttle fly Megaselia scalaris (Leow). With regards to carrion beetles (Coleoptera), representatives of two families were collected on the
Control pig during the duration of the experiment, the rove beetle Creophilus erythrocephalus Fabricius (family Staphylinidae) and clown beetles Carcinops pumilio (Erichson) (family Histeridae). In the suitcases, carrion beetles were only found in suitcase 4 and they were C. pumilio and Diamesus ss.pp. (family Silphidae) and. Adventive insects included ants (Hymenoptera: Formicidae), which were observed removing eggs from the Control pig and from the external parts of the suitcases in the first two weeks of the experiment, ground beetles (Coleoptera: Carabidae), found on the Control pig between day 9 and 13, and earwigs (Dermaptera: Forficulidae), observed only outside S2 between day 9 and 15. White garden snails (Theba pisana (Müller), Gastropoda: Helicidae) were found infesting only the external part of S4 between day 12 and 17.

Table 3: Colonization on the Control pig during the period of the experiment.

\begin{tabular}{|c|c|c|c|c|c|c|c|c|c|c|c|c|c|c|c|c|c|c|c|c|c|c|c|c|c|c|c|c|c|c|}
\hline \multirow{3}{*}{$\begin{array}{l}\text { Or- } \\
\text { der }\end{array}$} & \multirow{3}{*}{ Family } & \multirow{3}{*}{$\begin{array}{l}\text { Ge- } \\
\text { nus- } \\
\text { Spe- } \\
\text { cies }\end{array}$} & \multicolumn{28}{|c|}{ Colonization on the Control pig } \\
\hline & & & \multicolumn{28}{|c|}{ Days of Collection } \\
\hline & & & 1 & 2 & 3 & 4 & 5 & 6 & 7 & 8 & 9 & 10 & 11 & 12 & 13 & 14 & 15 & 16 & 17 & 18 & 19 & 21 & 23 & 25 & 28 & 30 & 33 & 36 & 38 & 42 \\
\hline \multirow{6}{*}{$\begin{array}{l}\text { Dip- } \\
\text { tera }\end{array}$} & \multirow{4}{*}{$\begin{array}{l}\text { Cal- } \\
\text { lipho- } \\
\text { ridae }\end{array}$} & $\begin{array}{l}\text { Chry- } \\
\text { somya } \\
\text { rufifa- } \\
\text { cies }\end{array}$ & & & & & & & & $\mathrm{L}$ & $\mathrm{L}$ & $\mathrm{L}$ & & $\mathrm{L}$ & $\mathrm{L}$ & $\mathrm{L}$ & $\mathrm{L}$ & $\mathrm{L}$ & $\mathrm{L}$ & $\mathrm{L}$ & $\mathrm{L}$ & $\mathrm{L}$ & $\mathrm{L}$ & $\mathrm{L}$ & $\mathrm{L}$ & $\begin{array}{l}\mathrm{L}, \\
\mathrm{P}, \\
\mathrm{P}^{*}\end{array}$ & $\begin{array}{l}\mathrm{P}, \\
\mathrm{P}^{*}\end{array}$ & $\begin{array}{l}\mathrm{P} \\
\mathrm{P}^{*}\end{array}$ & $\begin{array}{l}\mathrm{P} \\
\mathrm{P}^{*}\end{array}$ & $\begin{array}{c}\mathrm{P} \\
\mathrm{P}^{*}\end{array}$ \\
\hline & & $\begin{array}{l}\text { Cal- } \\
\text { liph- } \\
\text { ora } \\
\text { dubia }\end{array}$ & & & & & $\mathrm{L}$ & $\mathrm{L}$ & $\mathrm{L}$ & & $\mathrm{L}$ & $\mathrm{L}$ & & & & & & & & & & & & & & & & & & \\
\hline & & $\begin{array}{l}\text { Cal- } \\
\text { liph- } \\
\text { ora } \\
\text { albi- } \\
\text { fron- } \\
\text { talis }\end{array}$ & $\mathrm{E}$ & $\mathrm{E}$ & $\mathrm{E}$ & $\mathrm{E}$ & $\begin{array}{l}\text { E, } \\
\mathrm{L}\end{array}$ & $\mathrm{L}$ & $\mathrm{L}$ & & $\mathrm{L}$ & $\mathrm{L}$ & $\mathrm{L}$ & & & $\mathrm{L}$ & & $\mathrm{L}$ & $\mathrm{L}$ & $\mathrm{L}$ & & & & & & & & & & \\
\hline & & $\begin{array}{l}\text { Lucilia } \\
\text { serica- } \\
\text { ta }\end{array}$ & $\mathrm{E}$ & $\mathrm{E}$ & $\mathrm{E}$ & $\mathrm{E}$ & $\begin{array}{l}\text { E, } \\
\text { L }\end{array}$ & & $\mathrm{L}$ & $\mathrm{L}$ & $\mathrm{L}$ & $\mathrm{L}$ & & & & & & & & & & & & & & & & & & \\
\hline & $\begin{array}{c}\text { Fannii- } \\
\text { dae }\end{array}$ & $\begin{array}{c}\text { Fan- } \\
\text { nia ca- } \\
\text { nicu- } \\
\text { laris }\end{array}$ & & & & & & & & & & & & & & & & & $\mathrm{L}$ & & & & & & & & & & & \\
\hline & $\begin{array}{c}\text { Musci- } \\
\text { dae }\end{array}$ & $\begin{array}{c}\text { Mus- } \\
\text { cina } \\
\text { stabu- } \\
\text { lans }\end{array}$ & & & & & & & & & & & & & & & & $\mathrm{L}$ & $\mathrm{L}$ & $\mathrm{L}$ & & $\mathrm{L}$ & $\mathrm{L}$ & L & $\mathrm{L}$ & $\mathrm{L}$ & $\mathrm{L}$ & $\mathrm{L}$ & $\mathrm{L}$ & $\mathrm{L}$ \\
\hline \multirow{2}{*}{$\begin{array}{l}\text { Hy- } \\
\text { men } \\
\text { op- } \\
\text { tera }\end{array}$} & $\begin{array}{l}\text { Vespi- } \\
\text { dae }\end{array}$ & ss.pp. & & & & & & & & A & A & A & & & & & A & A & $\mathrm{A}$ & A & A & A & A & A & A & $\mathrm{L}$ & & & $\mathrm{L}$ & \\
\hline & $\begin{array}{c}\text { Formi- } \\
\text { cidae }\end{array}$ & ss.pp. & & & A & A & A & A & A & A & A & A & $\mathrm{A}$ & A & $\mathrm{A}$ & A & $\mathrm{A}$ & A & $\mathrm{A}$ & A & A & A & & & & & A & A & $\mathrm{A}$ & \\
\hline \multirow{3}{*}{$\begin{array}{l}\text { Co- } \\
\text { le- } \\
\text { op- } \\
\text { tera }\end{array}$} & $\begin{array}{l}\text { Stap } \\
\text { hylini- } \\
\text { dae }\end{array}$ & $\begin{array}{l}\text { Creo- } \\
\text { philus } \\
\text { eryth- } \\
\text { ro- } \\
\text { cepha- } \\
\text { lus }\end{array}$ & & & & & & & & & & & & & & & & & & & A & A & A & A & A & A & A & A & $\mathrm{A}$ & \\
\hline & $\begin{array}{l}\text { Histe- } \\
\text { ridae }\end{array}$ & $\begin{array}{l}\text { Carci- } \\
\text { nops } \\
\text { pum- } \\
\text { ilio }\end{array}$ & & & & & & & & & & & A & A & $\mathrm{A}$ & A & A & A & $\mathrm{A}$ & A & A & A & A & A & A & A & A & A & $\mathrm{A}$ & \\
\hline & $\begin{array}{c}\text { Carabi- } \\
\text { dae }\end{array}$ & ss.pp. & & & & & & & & & A & A & A & A & $\mathrm{A}$ & & & & & & & & & & & & & & & \\
\hline
\end{tabular}


Table 4: Colonization by insects inside each of the suitcases on their respective opening day.

\begin{tabular}{|c|c|c|c|c|c|c|c|}
\hline \multirow{3}{*}{ Order } & \multirow{3}{*}{ Family } & \multirow{3}{*}{ Genus-Species } & \multicolumn{5}{|c|}{ Insect Colonization inside each of the suitcase } \\
\hline & & & S1 & S2 & S3 & S4 & S5 \\
\hline & & & day 14 & day 21 & day 28 & day 36 & day 42 \\
\hline \multirow{5}{*}{ Diptera } & \multirow{2}{*}{ Calliphoridae } & Chrysomya rufifacies & & $\mathrm{L}, \mathrm{P}$ & $\mathrm{L}, \mathrm{P}^{*}$ & L, P & $\mathrm{L}, \mathrm{P}$ \\
\hline & & Calliphora albifrontalis & $\mathrm{L}$ & & & & \\
\hline & Fanniidae & Fannia canicularis & L, P & $\mathrm{P}$ & $\mathrm{P}$ & $\mathrm{P}$ & $\mathrm{P}$ \\
\hline & Muscidae & Muscina stabulans & E, L & $\mathrm{L}$ & $\mathrm{L}$ & E, L & $\mathrm{L}$ \\
\hline & Phoridae & Megaselia scalaris & $\mathrm{L}, \mathrm{P}$ & $\mathrm{L}, \mathrm{P}$ & $\mathrm{P}$ & $\mathrm{P}, \mathrm{Pu}$ & $\mathrm{P}, \mathrm{Pu}$ \\
\hline Hymenoptera & Vespidae & ss.pp. & A & & & & A \\
\hline \multirow{2}{*}{ Coleoptera } & Histeridae & Carcinops pumilio & & & & A & \\
\hline & Silphidae & Diamesus ss.pp. & & & & A & \\
\hline $\begin{array}{c}\text { E= Eggs; } \mathrm{L}=\text { Larva; } \mathrm{P}=\text { Pupa; } \mathrm{P}^{*}=\text { Parasited pupa; } \\
\text { Pu= puparium; } \mathrm{A}=\text { Adult }\end{array}$ & & & & & & & \\
\hline
\end{tabular}

Table 5: Colonization on the Control pig and on the external part of the suitcases N.A. = not applicable as the suitcase was removed after the opening.

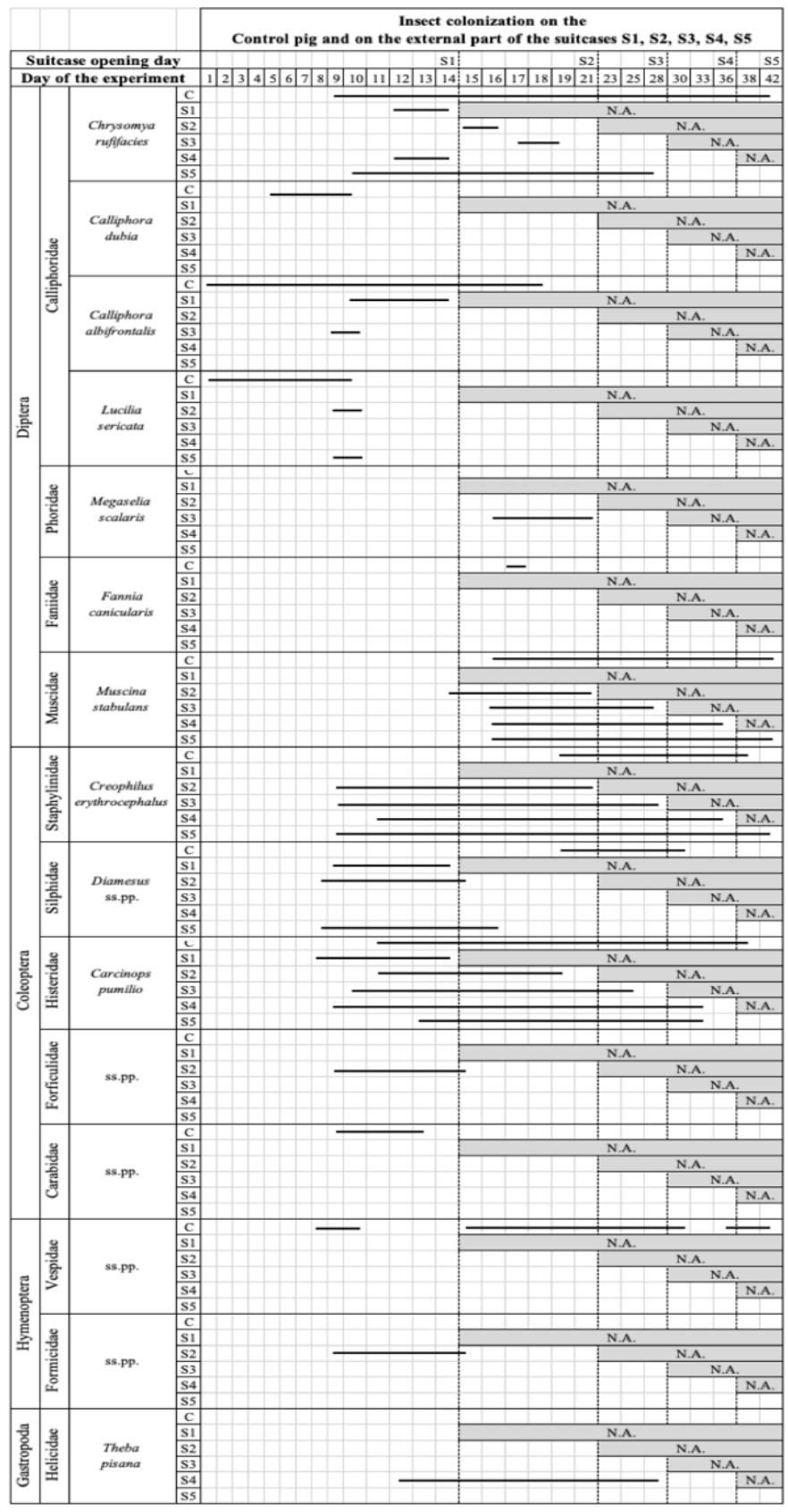

The insects attracted by the Control pig and by the suitcases were similar. However, differences in the timing of insect colonisation between the Control pig and pigs in the suitcases were clearly evident (Table 3,4,5). Adult blowflies were attracted to the Control pig within minutes of positioning (day 0 of the experiment), while fly activity was observed around the suitcases only on day 1. Eggs of the blowfly C. albifrontalis and L. sericata (Meigen), were observed inside the mouth and behind the left ear of the Control pig on day 1 , whereas fly eggs were not observed outside any of the suitcases until day 9 (Figure 4). Fly larvae were first recorded on the Control pig on day 5, however, larvae were not present outside the suitcases until day 9. The major difference in insect colonization between the Control pig and the pigs inside the suitcases was the presence of scuttle flies inside all of the suitcases but were absent on the Control pig. Lesser houseflies were present inside all suitcases but were only observed on the Control pig on day 17. Scuttle flies and lesser houseflies were the first colonizers inside the suitcases as both larvae and pupae were observed and collected inside the first suitcase opened on day 14.

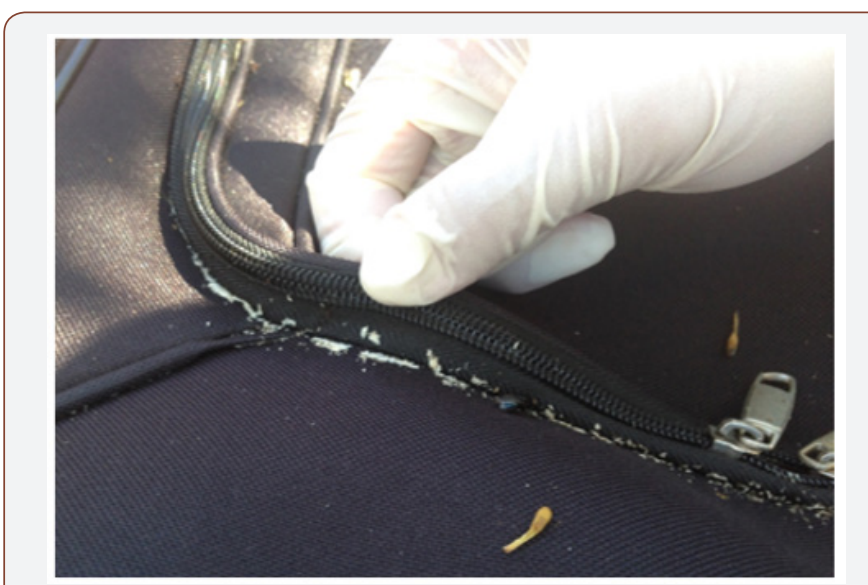

Figure 4: Oviposition on the suitcase zipper on day 9.

\section{Discussion}

The Control pig was skeletal in 42 days; however, the study was not long enough for the pigs in the suitcases to fully decompose. When considering an exposed pig, changes in climatic factors such 
as temperature, rainfall, and relative humidity affect the rate of carrion decomposition which in turn varies the number of days to complete decomposition [30]. This study was performed over the Austral autumn season (April-May) in Perth, Western Australia. When comparing the rate of decomposition of exposed pigs in Western Australia with other regions of the world that sit below the equator, the number of days needed for a pig to fully decompose are 40 days in Western Australia [31], 14 days in Malaysia [32], 25 days in Hawaii [33], 40 days in Brazil [30], and 83 days in Columbia [32] The above differences are a consequence of the climatic conditions in each of these unique geographic regions [33]. Previous research has identified differences in insect succession patterns between different seasons and geographic regions in Western Australia for carcasses placed on the surface [34]. The effect of temperature on the developmental rate of insects is widely known [6,35]. Insect activity and larval development rate will increase as temperature increases, and this ultimately increases the rate of decomposition [36]. However, in this study, the results in (Figure 1) did not show a significant difference between the temperatures of the Control pig and the pigs in the suitcases. This could be due to the fact that this study was designed with all the pigs in suitcases placed in shaded areas. The relative humidity registered outside the Control pig and inside the suitcases was significantly different (Figure 2). This was a natural consequence of the body fluids and the rain trapped in the suitcases, compared with the Control pig where these fluids drained from the body and seeped into the surrounding soil. As rainfall was registered only from day 13 , this environmental factor did not affect the establishment of colonization or the decomposition process on both the Control pig and inside/outside the suitcases. The presence of rainfall combined with body fluids did influence the production of adipocere in the S5-42 [37].

The second most important variable affecting the decomposition rate of a cadaver, after temperature, is the access of insects to the carrion [38]. In this study only the Control pig was exposed and the other five were pigs concealed in suitcases which restricted insect access. Within the first few hours following exposure flies will visit and oviposit on the carcass. Odors produced by the Control pig were the most likely reason why adult blowflies were attracted to the carcass, leading to oviposition in most of the natural orifices such as ears, eyes, mouth, nose and genital regions [2]. On day 1 of this experiment, fly eggs (C. albifrontalis and L. sericata) were observed in the mouth of the Control pig, however, no eggs were found on any of the suitcases. At the end of the first week there were larvae present on the control pig. Goff compared studies of carrion placed outdoors and indoors and demonstrated that there were significant differences in insect colonization [39]. Also, in the case of this experiment, while C. albifrontalis, Ch. rufifacies, F. canicularis and M. stabulans were present on both the Control pig and inside some of the suitcases, C. dubia and L. sericata were only present on the Control pig and M. scalaris only in some of the suitcases (Tables 3, 4). These insect patterns recorded on the Control pig represent the typical pattern of decomposition in Western Australia during the Austral autumn [40]. Despite several bodies being found concealed in suitcases [17-21], the only research to date on this matter has been performed in the UK [16], while in Australia the only research regarding restricted access environments has been conducted on bodies in vehicles [9]. However, to make comparisons between these vastly different restricted access environments are trite as they are very different environments, and with no control of any variables between each experimental design little can be concluded $[9,10,15]$. A body concealed in a suitcase has fewer egg deposition sites for the female flies except on the suitcase. In this study all the suitcases had eggs deposited around the lining of the zippers and underneath the suitcases by day 9 (Figure 4). Ants were observed removing eggs from the external part of the suitcases and parasitic wasps were observed in fly pupae from the Control pig and the pigs inside of the suitcases $[41,42]$. Neither of these species were identified. Parasitoid wasps sting and lay their eggs in the bodies of other arthropods, sooner or later causing the death of their host. $[41,42]$. These parasitic wasps were observed on most days in $C h$. rufifacies pupae sampled from the Control pig and in S5.

Scuttle flies are an important species in relation to concealed bodies and are known to burrow down in soil to reach buried bodies [43]. These species are small enough to get inside a concealed suitcase through the zippers and the gaps between the attached wheels on the bottom of the suitcase. Larvae and pupae were found outside the suitcase, particularly underneath where the suitcase lay on the ground. The UK study realized that entry into the suitcases was through the zippers with oviposition occurring within 48 hours, whereas this study determined that there was a delay of 9 days before oviposition and up to 14 days before colonization was detected on and in the suitcases.

\section{Conclusion}

It is necessary to understand the unique taphonomy processes that occur when a body is concealed. Although numerous efforts have been made to understand these processes, minimal research has been specifically related to concealment within a suitcase [16]. This study and the UK research have focused on zip-sealed travelling suitcase and the effect it has on insect succession. The UK study concluded that the design of the zip teeth is just one of many factors that affect the ability of insect colonization on the enclosed remains. The current study, although preliminary, has attempted to build on the UK study and gain some insight into how long it takes for flies to colonize remains inside a suitcase albeit in Australia. Although this research is limited in its scope, it will certainly focus any future forensic investigations when remains are located in a concealed environment.

\section{Acknowledgement}

The Authors would like to thank Murdoch University for the use of the study site and for providing the costs associated with the set up of the experiment. In particular, the Authors would like to thank Kim Thomas for granting the access to the study site.

\section{Conflict of Interest}

No conflict of interest. 


\section{References}

1. Haskell NH, RE Williams (2009) Entomology \& Death: A Procedura Guide. $2^{\text {nd }}$ (edn.), Forensic Entomology Partners, Clemenson, SC, USA.

2. Byrd JH, JL Castner (2010) Forensic Entomology - The utility of arthropods in legal investigation. $2^{\text {nd }}$ (edn.), CRC Press, Boca Raton, FL, USA.

3. Amendt J, Goff ML, Campobasso CP, Grassberger M (2010) Current Concepts in Forensic Entomology, Springer, 2010.

4. Greenberg B, JC Kunich (2002) Entomology and the law-flies as forensic indicators. Cambridge, UK, 2002.

5. Amendt J, R Zehner, R Krettek (2004) Forensic entomology, Naturwissenschaften 91: 51-65.

6. Greenberg B (1991) Flies as forensic indicators. J Med Entomol 28(5): 565-577.

7. Magni P, Massimelli M, Messina R, Mazzucco P, Di Luise E (2008) Entomologia Forense. Gli insetti nelle indagini giudiziarie e medicolegali. Ed. Minerva Medica.

8. Catts EP, ML Goff (1992) Forensic entomology in criminal investigations Annu Rev Entomol 37: 253-272.

9. Voss SC, SL Forbes, IR Dadour (2008) Decomposition and insect succession on cadavers inside a vehicle environment. Forensic Sci Med Pathol 4(1): 22-32.

10. Anderson GS (2011) Comparison of decomposition rates and faunal colonization of carrion in indoor and outdoor environments. J Forensic Sci Int 56(1): 136-142.

11. Reibe S, B Madea (2010) How promptly do blowflies colonise fresh carcasses? A study comparing indoor with outdoor locations. Forensic Sci Int 195(1-3): 52-57.

12. Magni PA, M Borrini, IR Dadour (2013) Human remains found in two wells: a forensic entomology perspective. Forensic Sci Med Pathol 9(3): p. 413-417.

13. Gunn A, J Bird (2011) The ability of the blowflies Calliphora vomitoria (Linnaeus), Calliphora vicina (Rob-Desvoidy) and Lucilia sericata (Meigen) (Diptera: Calliphoridae) and the muscid flies Muscina stabulans (Fallen) and Muscina prolapsa (Harris) (Diptera: Muscidae) to colonise buried remains. Forensic Sci Int 207(1-3): 198-204

14. Ahmad A, Ahmad AH, Dieng H, Satho T, Ahmad H et al. (2011) Cadaver wrapping and arrival performance of adult flies in an oil palm plantation in northern Peninsular Malaysia. J Med Entomol 48(6): 1236-1246.

15. Goff LM (1992) Problems in estimation of postmortem interval resulting from the wrapping of a corpse: a case study from Hawaii. J Agr Entomol 9(4): 237-243.

16. Bhadra P, AJ Hart, MJR Hall (2014) Factors affecting accessibility to blowflies of bodies disposed in suitcases. Forensic Sci Int 239: 62-72.

17. AAP (2003) Man jailed over bodies in suitcase. The Sydney Morning Herald.

18. AFP (2015) Corpse found in suitcase after being left for one month in busy Tokyo train station. ABC News.

19. AAVV (2015) Girl in suitcase identified as Khandalyce Kiara Pearce; mother Karlie Jade Pearce-Stevenson found in Belanglo State Forest. ABC News.

20. Partridge E (2019) Ex-boyfriend suspected of killing Sydney dentist Preethi Reddy dies in car crash. 9 News.

21. Sapwell T (2018) Body-in-suitcase murder: Ah Ping Ban jailed for life for killing ex-wife, dumping body in Swan River. 9 News.

22. Dadour IR, Cook DF, Fissioli JN, Bailey WJ (2001) Forensic entomology: application, education and research in Western Australia. Forensic Sci Int 120(1-2): 48-52.
23. P Armstrong, KD Nizio, KA Perrault, SL Forbes (2016) Establishing the volatile profile of pig carcasses as analogues for human decomposition during the early postmortem period. Heliyon 2(2): e00070.

24. Commonwealth Scientific and Industrial Research Organization, CSaIR (1992) The Insects of Australia: a Textbook for Students and Research Workers. $2^{\text {nd }}($ edn.), Ithaca, Cornell University Press, United States.

25. Amendt J, Campobasso CP, Gaudry E, Reiter C, LeBlanc HN (2007) Best practice in forensic entomology - Standards and guidelines. Int J Legal Med 121(2): 90-104.

26. Prakash A (2009) Laboratory Manual of Entomology. New Age International Pvt Ltd Publishers.

27.Zumpt F (1965) Myiasis in man and animals in the Old World. Butterworths, London.

28. Zumpt F (1956) Calliphoridae (Diptera: Cyclorrhapha) Part I Calliphorini and Chrysomyiini. Explor, Parc. nat. Albert, Miss, de Witte 87 pp: 200.

29. Payne JA (1965) A summer carrion study of the baby pig Sus scrofa Linnaeus. Ecology 46(5): 592-602.

30. De Carvalho LML, AX Linhares (2001) Seasonality of insect succession and pig carcass decomposition in a natural forest area in southeastern Brazil. J Forensic Sci 46(3): 604-608.

31. Bornemissza G (1957) An analysis of Arthropod succession in Carrion and the effect of its decomposiion on the soil fauna. Aust J Zool 5(1): $1-12$.

32. Heo CC, Mohamad AM, Ahmad Firdaus MS, Jeffery J, Baharudin O (2007) A preliminary study of insect succession on a pig carcass in a palm oil plantation in Malaysia. Trop Biomed 24(2): 23-27.

33. Martinez E, P Duque, M Wolff (2007) Succession pattern of carrionfeeding insects in Paramo, Colombia. Forensic Sci Int 166(2-3): 182-189.

34. Sharanowski BJ, EG Walker, GS Anderson (2008) Insect succession and decomposition patterns on shaded and sunlit carrion in Saskatchewan in three different seasons. Forensic Sci Int 179(2-3): 219-240.

35. Voss SC, H Spafford, IR Dadour (2009) Annual and seasonal patterns of insect succession on decomposing remains at two locations in Western Australia. Forensic Sci Int 193(1-3): 26-36

36. Ames C, B Turner (2003) Low temperature episodes in development of blowflies: implications for postmortem interval estimation. Med Vet Entomol 17(2): 178-186.

37. Shean BS, L Messinger, M Papworth (1993) Observations of differential decomposition on sun exposed v. shaded pig carrion in coastal Washington State. J Forensic Sci 38(4): 938-949.

38. Forbes SL, Stuart BH, Dadour IR, Dent BB (2004) A preliminary investigation of the stages of adipocere formation. J Forensic Sci 49(3): 566-574.

39. Mann RW, Bass WM, Meadows L (1990) Time since death and decomposition of the human body: variables and observations in case and experimental field studies. J Forensic Sci 35(1): 103-111.

40. Goff LM (1991) Comparison of insect species associated with decomposing remains recovered inside dwellings and outdoors on the island of Oahu, Hawaii. J Forensic Sci 36(3): 748-753.

41. Voss SC, H Spafford, I Dadour (2010) Temperature-dependant development of Nasonia vitripennis on five forensically important carrion fly species. Entomol Exp Appl 135(1): 37-47.

42. Voss SC, H Spafford, I Dadour (2010) Host location and behavioural response patterns of the parasitoid, Tachinaephagus zealandicus Ashmead (Hymenoptera: Encyrtidae), to host and host-habitat odours. Med Vet Entomol 24: 189-198.

43. Smith KGV (1986) A Manual of Forensic Entomology. Trustees of the British Museum, Natural History and Cornell University Press, London. 